\title{
Involvement of bilateral posterior limb of internal capsule in hypernatraemic dehydration
}

\author{
Sooraj Patil, ${ }^{1}$ Chandana Bhagwat, ${ }^{1}$ Arushi Gahlot Saini, ${ }^{1}$ Sameer Vyas ${ }^{2}$
}

${ }^{1}$ Pediatrics, Postgraduate Institute of Medical Education and Research, Chandigarh, Chandigarh UT, India

${ }^{2}$ Radiodiagnosis, Postgraduate Institute of Medical Education and Research, Chandigarh, Chandigarh UT, India

Correspondence to Dr Arushi Gahlot Saini, doctorarushigahlot@gmail.com

Accepted 30 May 2018

\section{Check for updates}

To cite: Patil S, Bhagwat $C$, Saini AG, et al. BMJ Case Rep Published Online First: [please include Day Month Year]. doi:10.1136/bcr-2018 225101

\section{DESCRIPTION}

A 3-month-old male infant presented with loose stools and vomiting for the past 2 weeks and altered sensorium for the past 5 days. He was being administered inadequately diluted oral rehydration solution. On examination, he had moderate encephalopathy, depressed anterior fontanel and doughy skin. Laboratory investigations showed serum sodium $200 \mathrm{mEq} / \mathrm{L}$, potassium $6.1 \mathrm{mEq} / \mathrm{L}$, chloride $129 \mathrm{mEq} / \mathrm{L}$, urea $136 \mathrm{mg} / \mathrm{dL}$ and creatinine $0.7 \mathrm{mg} / \mathrm{dL}$. MRI of the brain showed predominant involvement of bilateral posterior limbs of internal capsule and genu with diffusion restriction (figure $1 \mathrm{~A}-\mathrm{F}$ ). The baby improved with administration of free water, supportive care and gradual reduction of serum sodium. There were no seizures, and encephalopathy improved by day 3 of hospitalisation. At 3-month follow-up, he has normal development, absence of seizures or focal motor deficits.

Hypernatraemic dehydration classically results in subdural, subarachnoid or intraparenchymal haemorrhages and cerebral venous sinus thromboses due to intracellular water-loss and significant brain shrinkage. ${ }^{1}$ Smaller haemorrhages at the brain surface or inside the parenchyma result from direct endothelial damage, whereas large subdural bleeds result from tearing of bridging veins in the subdural space over the brain. Severe hypernatraemia increases the osmolality of the blood and causes water to move from the brain into the blood circulation. As a counter-reactive mechanism to this

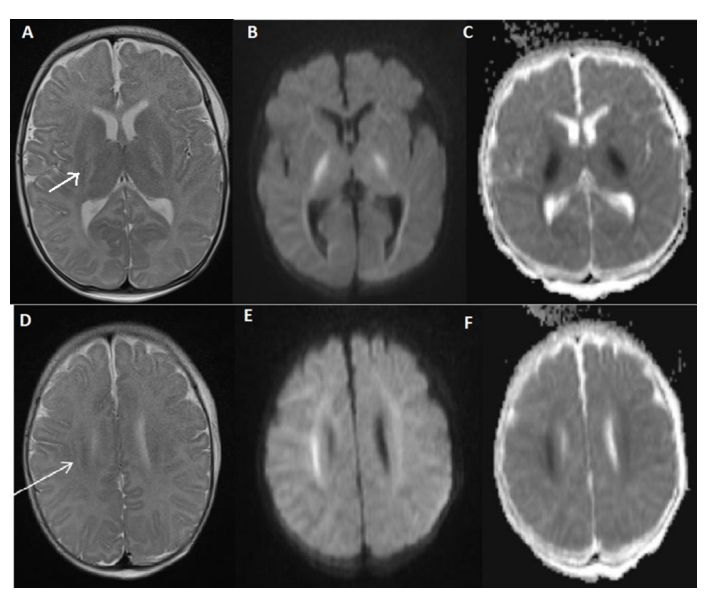

Figure 1 (A-F) MRI brain on day 4 of illness, axial T2 ( $A$ and $D)$, diffusion-weighted ( $B$ and $E$, $b$ value of 1000) and apparent diffusion-coefficient ( $C$ and $F$ ) images showing hyperintensities with diffusion restriction in bilateral posterior limbs of internal capsule and centrum semiovale (arrow). No areas of haemorrhages or contrast enhancement were seen. osmotic insult, the neurons produce intracellular osmolytes, known as 'idiogenic osmoles', to create hyperosmolarity inside the cells and retain water. A very slow dissipation of these idiogenic osmoles results in persistent water retention, neuronal and glial cell swelling and cerebral oedema. ${ }^{2}$ These osmotic changes cause intramyelinic oedema and splitting of myelin lamellae in the myelinated fibres of the internal capsule and corpus callosum and result in diffusion restriction and reduction in apparent diffusion coefficient. ${ }^{2}$ On the contrary, the diffusion restriction and reduction in apparent diffusion coefficient in the unmyelinated fibres in the brain has been proposed to be secondary to glial and axonal swelling. ${ }^{2}$ Our patient presented with these peculiar neuroimaging features restricted to the posterior limb of internal capsule and genu secondary to hypernatraemic dehydration, which have been scarcely described.

\section{Learning points}

Radiological manifestations of hypernatraemic dehydration, especially in cases where there has been no rapid correction known to cause myelin oedema, are less known.

- Hypernatraemic dehydration classically results in subdural, subarachnoid or intraparenchymal haemorrhages and cerebral venous sinus thromboses.

- Isolated involvement of posterior limb of internal capsule and genu is peculiar.

Contributors SP and CB: original drafting of the manuscript. AGS: original drafting and revising the manuscript for intellectual content. SV: analysis of radiological data and critical review of manuscript.

Funding The authors have not declared a specific grant for this research from any funding agency in the public, commercial or not-for-profit sectors.

Competing interests None declared.

Patient consent Guardian consent obtained.

Provenance and peer review Not commissioned; externally peer reviewed.

(C) BMJ Publishing Group Ltd (unless otherwise stated in the text of the article) 2018. All rights reserved. No commercial use is permitted unless otherwise expressly granted.

\section{REFERENCES}

1 Finberg L, Luttrell C, Redd H. Pathogenesis of lesions in the nervous system in hypernatremic states. II. Experimental studies of gross anatomic changes and alterations of chemical composition of the tissues Pediatrics 1959:23:46-53.

2 Righini A, Ramenghi L, Zirpoli S, et al. Brain apparent diffusion coefficient decrease during correction of severe hypernatremic dehydration. AJNR Am J Neuroradiol 2005;26:1690-4. 
Copyright 2018 BMJ Publishing Group. All rights reserved. For permission to reuse any of this content visit http://group.bmj.com/group/rights-licensing/permissions.

BMJ Case Report Fellows may re-use this article for personal use and teaching without any further permission.

Become a Fellow of BMJ Case Reports today and you can:

- Submit as many cases as you like

- Enjoy fast sympathetic peer review and rapid publication of accepted articles

Access all the published articles

- Re-use any of the published material for personal use and teaching without further permission

For information on Institutional Fellowships contact consortiasales@bmjgroup.com

Visit casereports.bmj.com for more articles like this and to become a Fellow 